In: J. Ebbesson et al (eds.),

International Law and Changing Perspectives of Security (Brill, 2014)

\title{
International Law in the Age of Asymmetrical Warfare, Virtual Cockpits and Autonomous Robots
}

\author{
Mark Klamberg
}

1

\section{Introduction}

The use of unmanned combat air vehicles (UCAVs) in the context of counterterrorism operations challenges the traditional conception of security, it is part of a change in the perception of nature and sources of threats. For states with access to it, modern technology allows increasing distance to be put between weapons operators and their targets. In addition, we are heading into a major military technology transformation, as manned platforms will largely be replaced by unmanned autonomous systems. The United States is increasingly relying upon UCAVs, also known as combat drones or drones to target and kill enemies. The US is, however, not the only player in the field - at least 40 nations are active. For example, in 2010 Iran revealed an unmanned bomber and China has a very ambitious programme. ${ }^{2}$

This text will focus on some of the most contentious issues. First, will the use of UCAVs affect how we perceive state intervention in the territory of other states? Second, the Us use UCAVs to target enemies as a part of its counterterrorism operations. This has raised several concerns, including a discussion on the relevant legal framework. Should counterterrorism operate under the armed-conflict or law enforcement model? Under what circumstances are targeted killings allowed under international law? This discussion is influenced by the fact that almost all targeted killings are directed against non-State actors and generally carried out while the targeted person is not visibly engaged in active combat. ${ }^{3}$ Finally, the use of lethal autonomous robotics (LARs) would

1 I would like to thank Pål Wrange and Fredrik Holst who provided helpful comments on the manuscript or parts thereof at various stages in its development. As far as shortcomings are concerned, they are all attributable to the author.

2 Magnus Jändel and Fredrik Lindvall,'Military Robotics Transform the Face of War' in Emma Skeppström, Stefan Olsson and Åke Wiss (eds), Strategic Outlook (FOI 2012) 39, 41; HR Council, 'Report of the Special Rapporteur on Extrajudicial, Summary or Arbitrary Executions' (9 April 2013) UN Doc A/HRC/23/47 [26]; Nils Melzer, Human Rights Implications of the Usage of Drones and Unmanned Robots in Warfare, Study for the European Parliament's Subcommittee on Human Rights (2013) EXPO/B/DROI/2012/12 6.

3 Nils Melzer, Targeted Killing in International Law (Oxford University Press 2008) 56. 
increase the distance even more between the person who controls the use of force and the target, in that targeting decisions could be taken by the robots themselves. There are reasons to discuss whether such technology should be added to the arsenals of states. Since robots lack moral agency they cannot be held legally responsible in any accustomed way. How is it possible to address this potential accountability gap?

The use of unmanned weapons platforms raises the question whether states to a larger extent will resort to the use of force and intervene in other states. This involves several potential issues, including (1) the cost of using UCAVs, (2) whether the use of UCAVs may constitute an act of aggression or an armed attack and (3) the relationship between jus in bello and jus ad bellum.

The use of traditional military force is costly both in terms of money and putting people in risk. Unmanned weapons platforms are much less costly than their manned counterparts and remove the risks for the personnel. This may make the use of force more easy. ${ }^{4}$ However, there is not yet any examples where an armed conflict has started with the use of unmanned weapons platforms. On the other hand, even if you cannot start an armed conflict with UCAVs, they may potentially be used to stay in a conflict and prolong it where a state in the absence of such weapons might have left, all other things being equal.

Some states might perceive the use of unmanned weapons platforms on the territory of other states falling short of aggression or an armed attack. Is this a tenable argument? Even if the assertion is true, does it matter? With this perception it may become easier to justify targeted killings of persons at least against those belonging to non-state actors, for example a terrorist group. ${ }^{5}$ In order to assess whether such policies are appropriate we first need to address the concepts use of force and aggression in general.

It is appropriate to distinguish between use of force, and the more narrow concepts armed attack and aggression. The occurrence of an armed attack give rise to the right to self-defence while aggression is one of the three alternative conditions for a decision of the Un Security Council (see article 39 of

\footnotetext{
4 Kenneth Anderson, 'Efficiency in Bello and Ad Bellum: Making the Use of Force too Easy?' in Claire Finkelstein, Jens David Ohlin and Andrew Altman (eds), Targeted Killings: Law and Morality in an Asymmetrical World (Oxford University Press 2012) 375-376.

5 Melzer (n 2) 7 .
} 
the UN Charter) to decide on enforcement measures. Both armed attack and aggression are serious forms of use of force. Even if it is uncertain whether the two concepts are synonymous they are adjacent. ${ }^{6}$ This means that lesser use of force although prohibited neither amounts to aggression nor an armed attack and as such does not give rise to the right to self-defence. For example, even if the training and military support for armed bands does not amount to aggression it does violate the prohibition on the use of force or intervention. ${ }^{7}$

A definition of aggression is contained in the annex of General Assembly Resolution 3314 (XXIX) of 14 December $1974 .{ }^{8}$ This is appropriate as the resolution is a consensual and time-tested document adopted by the General Assembly. ${ }^{9}$ Article 1 of the annex defines an act of aggression in general terms based almost word by word on article 2(4) of the UN Charter: 'the use of force by a State against the sovereignty, territorial integrity or political independence of another State, or in any other manner inconsistent with the Charter of the United Nations.' Article 2 provides that gravity of the act and its consequences should be taken into consideration. This would suggest that minor border incidents does not constitute aggression..$^{10}$ The systematic use of force by operating unmanned weapons platforms on a foreign state's territory is arguably more than border incidents. There is a list in article 3 which includes several acts which qualify as an act of aggression, where sub-paragraph (b) might cover the use of unmanned weapons platforms. It concerns bombardment by the armed forces of a State against the territory of another State or the use of any weapons by a State against the territory of another State. A narrow

Pål Wrange, Aggressionsbrottet och Internationella brottmålsdomstolen (Totalförsvarets folkrättsråd, Försvarsdepartementet 2011) 16.

7 Case Concerning Armed Activities on the Territory of the Congo (Democratic Republic of the Congo v Uganda) [2005] ICJ Reports 4, paras 160-161. 'The Court has considered whether the MLC's conduct was on the instructions of, or under the direction or control of' Uganda (art 8) and finds that there is no probative evidence by reference to which it has been persuaded that this was the case (...) even if the evidence does not suggest that the MLC's conduct is attributable to Uganda, the training and military support given by Uganda to the ALC, the military wing of the MLC, violates certain obligations of international law.'

8 Definition of Aggression, UNGA Res 3314 (14 December 1974) Un Doc A/RES/3314.

9 Stefan Barriga, 'Against the Odds: The Results of the Special Working Group on the Crime of Aggression' in Roberto Bellelli (ed), International Criminal Justice (Ashgate 2010) 630.

10 The ICJ Court distinguishes minor armed exchanges or 'frontier incidents' from attacks that give rise to the right of self-defense, Case Concerning the Military and Paramilitary Activities in and against Nicaragua (Nicaragua $v$ United States of America) [1986] ICJ Reports 4 (The Nicaragua case), paras 102-104; see also Wrange (n 6) 15. 
interpretation would be that use of force against non-state actors which are on the soil of a foreign state is not directed against the territory of that state. This is not crucial because the list is non-exhaustive, ${ }^{11}$ which means that other acts not specifically listed in the document may equally qualify as aggression, for example military action taken with the use of UCAVs. The gravity of the act is also relevant in order to determine whether an attack by the use of unmanned weapons amounts to an armed conflict, an issue revisited in section 3.2 of the present text.

Article 6 of resolution 3314 clarifies that the resolution does not enlarge or diminish the scope of the UN Charter, which means that grounds that preclude the wrongfulness of a use of force should be taken into account, including Security Council authorisation, the right to self-defence and consent of the territorial state. ${ }^{12}$ Thus the scope of the right to self-defence needs to be defined, especially in relation to the use of force as a means of self-defence against terrorism. There is no requirement in article $5^{1}$ on self-defence that armed attack is caused by a state which raises the question against whom may a state use self-defence. Before the events of 11 September 2001 the assumption was that for the purposes of article $5^{1}$ an armed attack meant the attack by a state against another state. The requirement that the attacker has to be a state was (and maybe still is) a part of international customary law which complements article 51 . The us response to the September 11 attacks can be justified in two different ways.

First, it could be argued that the widespread acceptance of other states towards us actions reflected a change in customary international law meaning that international law now accepts the use of force against a non-state actor as a response to large-scale terrorist acts. The us claims that it has the right to use military force, including targeting killings against al-Qaeda across the globe, provided that the territorial state concerned either is unwilling or unable to suppress the threat the target poses. ${ }^{13}$ This position may have some support in the law on neutrality which provides that a neutral state has the obligation to intervene against belligerent parties that uses the neutral state's territory. If the neutral state abstains from action, the belligerent parties may

\footnotetext{
11 UNGA Res 3314 (XXIX) (n 8), annex 'Definition of Aggression' art 4.

12 Claus Kreßand and Leonie von Holtzendorff, 'The Kampala Compromise on the Crime of Aggression' (2010) 8 Journal of International Criminal Justice 5, 1179, 1191-1192; Melzer (n 2) 22.

13 Harold Hongju Koh, 'The Obama Administration and International Law' (Speech at the Annual Meeting of the American Society of International Law, Washington DC, US Department of State, 11 September 2012).
} 
resort to counter-measures, including the use of force. ${ }^{14}$ On the other hand, it is questionable whether this right to self-defense may be extended for years and with no geographic limitations. ${ }^{15}$

A second, less radical, approach supported by us statements is that the de facto government of Afghanistan at the time of the September 11 attacks were complicit and responsible for the attacks. This would mean that the traditional interpretation of article $5^{1}$ to a large extent is intact. At the same time such an interpretation would arguably exclude the use of force outside the territory of Afghanistan under the parole of 'war against terrorism.'16 There is also a third position, namely that the US should have sought prior authorization for the use of force by the UN Security council and in absence of such authorization, Us actions against Afghanistan does not meet the requirement of self-defense. ${ }^{17}$

To summarize, the use of UCAVs may in the absence of any ground for legitimate use of force (Security Council authorisation, self-defence, consent) constitute aggression.

\subsection{Disentangling Targeted Killings and Drone Warfare}

One has to disentangle targeted killings and the technology of drone warfare, the two are not always linked.

Targeted killing may be defined as the intentional killing by a state of an individual identified in advance and not in the state's custody. ${ }^{18}$ Targeted killing may take place in conventional warfare through special operations that

14 Hague Convention V - Rights and Duties of Neutral Powers and Persons in Case of War on Land (adopted 18 October 1907) art 5; Ove Bring and Anna Körlof, Folkrätt för totalförsvaret (3rd edn, Norstedts Juridik 2002) 238-239; Jens David Ohlin, 'Targeting Co-belligerents' in Finkelstein, Ohlin and Altman (eds) (n 4) 71-72.

15 Mary Ellen O'Connell, 'Combatants and the Combat Zone' (2009) 43 University of Richmond Law Review 845, 853.

16 cf Ian Brownlie, Principles of Public International Law (6th edn, Oxford University Press 2003) 713-714; Ove Bring, Said Mahmoudi and Pål Wrange, Sverige och folkrätten (4th edn, Norstedts Juridik 2011) 166-167; Markus Gunneflo, The Life and Times of Targeted Killing (Lund University 2014) 197-198.

17 Said Mahmoudi, 'International Use of Force: Quo Vadis?' (2003-2004) 15 Juridisk Tidsskrift 2, 341, 349; Said Mahmoudi, 'Self-Defence and International Terrorism' (2006) 48 Scandinavian Studies in Law 203, 206.

18 Andrew Altman, 'Introduction' in Finkelstein, Ohlin and Altman (eds) (n 4) 5. 
narrowly focus operations through intelligence. It might also take place outside a conventional conflict belonging to a separate category with the following elements: intelligence-driven, often covert, sometimes operated by a non-military agency such as the CIA, aimed at 'high value' targets in global counterterrorism operations. Targeted killing can be carried with different techniques, either through the use of special forces with humans carrying out the attack or a drone aircraft operated from a distance. The bin Laden operation may exemplify a human-team conducted targeted killing. ${ }^{19}$ The rationale behind introducing the concept of targeting killing appears to have been to distinguish it from assassination. While assassination carries the connotation of illegality, the legality of target killing is determined by the applicable legal framework, ${ }^{20}$ as elaborated upon in section 3.2 .

From the perspective of conventional military operations a drone may be seen simply as an alternative air weapons platform. A missile may be launched from a drone in the same way as a weapon from a manned helicopter on a safe distance from the fighter or as a cruise missile from a Navy vessel. A missile launched by a drone arguably present the same legal issues as any other weapon system, the principles of necessity, distinction and proportionality still applies. One could also add the principle of precaution. ${ }^{21}$

Are drones per se prohibited under the rules of armed conflict (international humanitarian law - IHL)? There are no existing treaties that prohibit or restrict the development or use of drones. The question is rather whether a weapon in the normal operational circumstances for which it has been designed, that system is capable of being used in compliance with humanitarian law. From a technological point of view, attacks by human-controlled drones can be directed at specific military objectives and, in principle, the effects of such attacks on the target and the civilian population can be limited as required by humanitarian law. Therefore, currently operational armed drones do not, as such, constitute an indiscriminate means of warfare prohibited under humanitarian law. As argued in section 4 of this text, a different conclusion would have to be reached for the use of LARs in a fully autonomous mode, in which armed drones would make targeting decisions without human intervention. $^{22}$

\footnotetext{
19 Anderson (n 4) 379.

20 Gunneflo (n 16) 9-10, 188.

21 Additional protocol I to the 1949 Geneva Conventions (AP I) arts 57, 58.

22 Melzer (n 2) 27.
} 


\subsection{Armed-Conflict or Law Enforcement Model}

Two main legal models are conceivable in the context of counterterrorism operations, either such operations are governed by the rules of armed conflict (IHL) or law enforcement (international human rights law - IHRL). An inquiry into the international lawfulness of targeted killings arguably begin by questioning whether these operations are governed by IHL or IHRL. In order for IHL to be applicable there must exist a situation of armed conflict. ${ }^{23}$

The law-enforcement model which operates under IHRL suggests that terrorism should be dealt with by personnel, procedures and standards used in responding to any serious crimes: police, prosecution, judicial authorization of warrants, public trials, right to legal counsel, right for a suspect/defendant to examine the witnesses against him/her and to obtain attendance and examination of witnesses on his/her behalf and other elements of due process. Some deviations from standard procedure may be legitimate, for example to protect informers and state secrets, but the aim is to stick to as close as possible to standard procedures. This model rejects the idea of targeted killing of suspected or known terrorists apart from situations where an individual poses an imminent threat to the lives of civilians and lethal force is the only way to stop the threat. The use of lethal force is a measure of last resort. ${ }^{24}$ In addition to vengeance and retribution, social defence may also justify punishment under the law enforcement model. ${ }^{25}$ To rephrase and restate the argument, capture followed by trial is preferable to targeted killings: a dead terrorist can provide no information, the target may be misidentified and innocent are killed, killing somebody who has previously engaged in terrorism in the past will not serve any defensive purpose, innocent bystanders may be killed, risk of abuse where side-effects are ignored and the risk that unscrupulous regimes will exploit the legal permission when it kills political opponents who are not terrorists at all. ${ }^{26}$

The armed-conflict model which operates under IHL is based on the idea that the traditional model of war between two or several states may also be applied to the asymmetrical relationship between a state and terrorist organizations that seek to attack it. The model suggests that suspected and known terrorists should be treated as enemy combatants who should be met with military means. A military response to terrorism is legitimate as an act of selfdefence. Terrorists are unprivileged combatants because of their tactics,

\footnotetext{
23 Melzer ( $\left.\mathrm{n}_{3}\right) 55$.

$24 \quad \operatorname{Altman}(\mathrm{n} 18)$ 5-6; Melzer (n 2) 29-34.

25 Jeff McCahan, 'Targeted Killing: Murder, Combat or Law Enforcement' in Finkelstein, Ohlin and Altman (eds) (n 4) 136.

26 ibid [150].
} 
targeting civilians, who lack the legal and moral permission to kill anybody because they do not distinguish themselves from civilians. They are also war criminals because they target civilians. If captured terrorists it is legally permissible to try them in military courts where the due process standard are less rigorous than is found in civilian criminal courts. Under this model there is no obligation to try to capture a terrorist, instead it is permitted to target them with lethal force even if they are not posing an imminent threat to lives of others. The use of lethal force is not a measure of last resort. It is only forbidden to intentionally kill the enemy if and when he/she has surrendered and/or is incapable of fighting because of injury, ie hors de combat. ${ }^{27}$ This is consistent with the reality of warfare where a part is that military personnel run the risk of being individually targeted. ${ }^{28}$ McCahan argues that killing under the armedconflict model may only be justified as an act of defence and not by appeal to vengeance or retribution. ${ }^{29}$ However, as noted above defence may be a justification also under the law-enforcement model.

Some rules in IHRL are also applicable in armed conflicts. The ICJ has stated that 'the right not arbitrarily to be deprived of one's life applies also in hostilities. The test of what is an arbitrary deprivation of life, however, then falls to be determined by the applicable lex specialis, namely, the law applicable in armed conflict which is designed to regulate the conduct of hostilities' ${ }^{30}$ Not every use of force occurring during an armed conflict necessarily constitutes an 'act of war'. Whenever States resort to force outside the conduct of hostilities, for instance against suspected criminals, they must comply with law enforcement standards. ${ }^{31}$ This matter will be revisited in section 3.3 on direct participation in hostilities.

Further Melzer argues, the question of the applicability of IHRL during armed conflict must be distinguished from the question of its extraterritorial applicability. Protection for individuals under human rights treaties are normally limited to the 'jurisdiction' of a State party. ${ }^{32}$ In relation to human rights

$27 \quad \operatorname{Altman}(\mathrm{n} 18) 6-7$; $\operatorname{Melzer}(\mathrm{n} 2) 26$.

$28 \quad$ Melzer (n 2) 26.

29 McCahan (n 25) 135.

3o Legality of the Threat or Use of Nuclear Weapons (Advisory Opinion) [1996] ICJ Reports 4 [25].

$31 \quad \operatorname{Melzer}(\mathrm{n} 2) 5^{-16 .}$

32 European Convention for the Protection of Human Rights and Fundamental Freedoms as amended by Protocol No 11 (adopted 4 November 1950) 213 United Nations Treaty Series 221 art 1; International Covenant on Civil and Political Rights (adopted 16 December 1966) 999 United Nations Treaty Series 171 art 2(1); American Convention on Human Rights (adopted 22 November 1969) 1144 United Nations Treaty Series 123 art 1(2). cf African 
law, the notion of 'jurisdiction' has both a (primary) territorial and a (secondary) personal dimension. Thus, all persons finding themselves within the national borders of a State are presumed to come within its (territorial) jurisdiction. The European Court of Human Rights (ECtHR) has ruled that the territorial jurisdiction of a State extends beyond its national borders when that State exercises 'effective control of the relevant territory and its inhabitants abroad as a consequence of military occupation or through the consent, invitation or acquiescence of the Government of that territory, exercises all or some of the public powers normally to be exercised by that Government.'33 Even in the absence of territorial control, States have obligations under IHRL to the extent that their agents do, in fact, exercise physical power, authority or control over individuals. ${ }^{34}$ Similarly, the Legal Adviser at the us State Department Harold Koh argued in an internal memo, contrary to the us official position, that the International Covenant on Civil and Political Rights does 'impose certain obligations on a State Party's extraterritorial conduct.'35 Melzer has noted that very few human rights cases have gone as far as suggesting that a State's human rights obligations could also be violated through the use of military force involving neither territorial control nor personal custody, a scenario which would be particularly relevant for extraterritorial drone operations. The question whether human rights treaties are applicable is important in order to determine whether a particular human rights body may receive complaints. However, potential absence in jurisdiction for HR bodies does not preclude the lawfulness of extraterritorial operations involving the use of force against individuals. The international law prohibition on murder and extrajudicial killings does not necessarily depend on the applicability of particular human rights treaty regimes, because it is part of international customary law. ${ }^{36}$

Charter on Human and Peoples' Rights (adopted 27 June 1981) 1520 United Nations Treaty Series 217 art 1 .

33 Bankovic and Others $v$ Belgium and 16 Other Contracting States (dec) [GC] ECHR 2001-XII 333, para 71; Al-Skeini and Others $v$ the United Kingdom [GC] App no 55721/o7 (ECtHR, 7 July 2011), para 135 .

34 Issa and Others $v$ Turkey App no 31821/96 (ECtHR, 16 November 2004), para 71; Delia Saldias de Lopez v Uruguay (HRC, 29 July 1981) Un Doc CCPR/C/13/D/52/1979, paras 12.1-12.3.

35 Harold Koh, United Department of State, 'Memorandum Opinion on the Geographic Scope of the International Covenant on Civil and Political Rights' (19 October 2010), 4, made available through article by Charlie Savage, 'U.S. Seems Unlikely to Accept That Rights Treaty Applies to Its Actions Abroad' The New York Times (New York, 6 March 2014). 
How do we determine whether a situation should be characterized as an armed conflict and thus the applicable legal framework? Before the establishment of the UN, 'war' was understood as a formally declared, and mutually recognized, state of hostility between sovereign states. Peace and war concerned less the factual situation but more the formalized condition whether the entire law of peace (jus pacis) or the full law of war (jus in bello) applied. Under this state of war doctrine states employed in the absence of formal declaration or recognition of war, massive military force against each other without considering themselves in a state of war, which would have obliged them to respect the law of war. A turning point in this respect was the adoption of the Geneva Conventions of $1949 .{ }^{37}$ The applicable model was made dependent on the term 'armed conflict' which is used in the Conventions instead of the term 'war'. Pictet's commentary to the Geneva Conventions explains that the choice to use the term 'armed conflict' was intended to ensure that states could not avoid their responsibilities under the Conventions by simply labelling the conflict something other than war. The commentary states that '[a]ny difference arising between two States and leading to the intervention of armed forces is an armed conflict within the meaning of article 2, even if one of the Parties denies the existence of a state of war.' ${ }^{38}$ In other words, the existence of an armed conflict within the meaning of IHL depends on factual criteria and are not dependant on formal declarations. ${ }^{39}$ This expansion of the scope of IHL is commendable but ambiguity in the term 'armed conflict' may allow states to selectively claim the right to engage with military force in foreign territory against terrorists. Pictet viewed a perceived a risk that states wanted to avoid the application of the Conventions because of the abundance of obligations they entail. However, without forces on the ground, many of these obligations are irrelevant. States that are using drones operated remotely from the target only have incentives to invoke IHL. More specifically, IHL allows combatants to kill without warning. ${ }^{40}$ Similarly, terrorists often conceive of themselves as combatants but it may actually be against their interest

$37 \quad$ Melzer (n 3) 246.

38 Jean S Pictet (ed), The Geneva Conventions of 12 August 1949: Commentary (International Committee of the Red Cross 1952) 32. See also David Turns, The Law of Armed Conflict in Malcolm D Evans (ed), International Law (3rd edn, Oxford University Press 2010) 819 .

39 Melzer (n 2) 19.

40 Richard V Meyer, The Privilege of Belligerency and Formal Declarations of War in Finkelstein, Ohlin and Altman (eds) (n 4) 211-212. 
to be recognized as such because it allows a greater use of lethal force against them. ${ }^{41}$

Thus it is important to define under what circumstances an armed conflict exist and in turn whether military force may be used. The Tadić Appeals Chamber has stated that 'an armed conflict exists whenever there is a resort to armed force between States or protracted armed violence between governmental authorities and organized armed groups or between such groups within a State'. In other words, certain 'intensity requirements applicable to both international and internal armed conflicts' has to be exceeded for IHL to be applicable. ${ }^{42}$ Indicative factors of the 'intensity' criterion include the number, duration and intensity of individual confrontations; the type of weapons and other military equipment used; the number and calibre of munitions fired; the number of persons and type of forces partaking in the fighting; the number of casualties; the extent of material destruction; and the number of civilians fleeing combat zones. The involvement of the UN Security Council may also be a reflection of the intensity of a conflict. ${ }^{33}$ Thus, isolated drone attacks (compare with border incidents in section 2) does arguably not meet the requirement of protracted violence and does not constitute an armed conflict. This means that IHRL should be applicable in such situations.

One could argue that a mixed model is possible where a state pursues the law-enforcement model in relation to suspected and known terrorists within its territory and in states that are cooperative. When the suspected or known terrorist is outside the scope of the jurisdiction of the state, for example residing in a failed state, non-cooperative or a hostile state, the armed-conflict model may be applicable. It appears as the us acts under a mixed model. Following the killing of Usama Bin Laden, legal adviser at the us Department of State Harold Hongju Koh wrote that 'whether a particular individual will be targeted in a particular location will depend upon considerations specific to each case, including those related to the imminence of the threat, the sovereignty of the other states involved, and the willingness and ability of those states to suppress the threat the target poses. 44 This position may only be upheld when there is an on-going armed conflict and the targeted individual is directly participating in that conflict as argued in section 2 above and the next section.

\footnotetext{
$41 \quad$ McCahan (n 25) 142.

42 Prosecutor v Dusko Tadic aka 'Dule' (Decision on the Defence Motion for Interlocutory Appeal on Jurisdiction) ICTY-94-1 (2 October 1995), para 70.

43 Prosecutorv Haradinaj et al (Trial Judgment) ICTY-04-84-T (3 April 2008), para 49

$44 \operatorname{Koh}(\mathrm{n} 35)$.
} 


\subsection{Direct Participation in the Hostilities}

Even if an armed conflict exists, persons may only be targeted with military force if they are combatants. ${ }^{45}$ Does a terrorist qualify as a combatant? The principle of distinction requires that the parties to a conflict at all times distinguish between civilians and combatants. ${ }^{46}$ This is a principle of customary international law. ${ }^{47}$ Given the importance of the principle and its requirement to distinguish civilians and combatants, the two categories need to be defined. Even though the Fourth Geneva Convention (GC IV) concerns the protection of civilians, it still lacks a definition of what is a civilian. Article 50 of the additional protocol I to the 1949 Geneva Conventions (AP I) may serve as a starting point as it states that a 'civilian is any person who does not belong to one of the categories of persons referred to in' articles 4 A, (1), (2), (3) and (6) of the Third Geneva Convention (GC III) article 43 of AP I. Civilians are thus not (1) members of the armed forces of a party to the conflict or (2) members of militias or volunteers groups. ${ }^{48}$ In order to enjoy the specially protected status as a civilian they are strictly prohibited from participating in the hostilities, except in the exceptional case where they are participating in a levee en masse, in which case they shall be regarded as belligerents provided that they carry their arms openly and respect the laws and customs of war. ${ }^{49}$ If civilians participate in the hostilities, they may be directly attacked as if they were combatants. The interpretive guidance of the International Committee of the Red Cross (ICRC) provides that in order to qualify as direct participation in hostilities, a specific act must meet the following cumulative criteria:

1. the act must be likely to adversely affect the military operations or military capacity of a party to an armed conflict or, alternatively, to inflict death, injury, or destruction on persons or objects protected against direct attack (threshold of harm);

2. there must be a direct causal link between the act and the harm likely to result either from that act, or from a coordinated military operation of which that act constitutes an integral part (direct causation);

\footnotetext{
$45 \quad$ Melzer (n 3$) 56$.

46 AP I arts 48 and $51(2)$; Melzer (n 3 ) 300-327.

47 Legality of the Threat or Use of Nuclear Weapons (n 30), paras 78-79.

48 Avril McDonald, The Challenges to International Humanitarian Law and the Principles of Distinction and Protection from the Increased Participation of Civilians in Hostilities (The Asser Institute 2004) s 2.1.

49 Hague Convention IV - Respecting the Laws and Customs of War on Land and annexed regulations (adopted 18 October 1907); McDonald (n 48) s 2.1.
} 
3. the act must be specifically designed to directly cause the required threshold of harm in support of a party to the conflict and to the detriment of another (belligerent nexus). ${ }^{50}$

However, unlike combatants, civilians regain protection against direct attack as soon as their individual conduct no longer amounts to direct participation in hostilities. ${ }^{51}$ This poses a potential problem in asymmetrical conflicts if the non-state actor uses a hit-and-run operation which would oblige the armed forces of the state to act purely reactively.

To summarize, civilians that directly participate in hostilities, namely by committing acts that meet the threshold of harm, requirements on direct causation and belligerent nexus may be targeted under IHL. An alleged terrorist who resides in an area where there is an armed conflict but who is not directly participating in the hostilities is thus not a legitimate target under I HL.

\subsection{Personality and Signature Strikes}

Drone attacks are frequently distinguished either into personality or signature strikes. A personality strike' may be defined as those in which the attacker has a 'high degree of confidence' that it knows the precise identity of the target. A 'signature strike' is a drone attack that targets 'groups of men who bear certain signatures, or defining characteristics associated with terrorist activity, but whose identities aren't known. ${ }^{2}$ Both types of strikes can take place either within armed conflict or outside of it. Regardless of the type of strike, it has to either adhere to IHL or IHRL, as argued in section 3.2 above.

Personality strikes during an armed conflict are less problematic in relation to the principle of distinction. If the attacker has reliable information on the precise identity of the target and that target is either a combatant or a civilian participating in the hostilities, lethal force is permitted.

Signature strikes are more problematic. Heller argues that signature strikes are only legal if the following two questions both can be answered affirmatively: First, is the particular signature legally sufficient to establish that the victim of the strike is targetable? Secondly, is the evidence sufficient to

$5^{0}$ Nils Melzer, International Committee of the Red Cross, Interpretive Guidance on the Notion of Direct Participation in Hostilities under International Humanitarian Law (2009) 90 International Review of the Red Cross 991, 995-996. See also Kevin Jon Heller, “One Hell of a Killing Machine": Signature Strikes and International Law' (2013) 11 Journal of International Criminal Justice 89, 93.

$51 \quad$ Melzer (n 3$) 329$.

$5^{2}$ Heller (n 5o) $9^{\circ}$. 
determine that the targeted individual is engaged in the signature behaviour? Based on Heller's studies of statements of government officials, it appears as United States believes that at least 14 distinct signatures are sufficient to establish that a drone attack complies with the principle of distinction. Heller divide those signatures divide into three categories: (i) signatures that are legally adequate (planning attacks, transporting weapons, handling explosives, Al-Qaeda compound, Al-Qaeda training camp); (ii) signatures that are never legally adequate (military-age male in area of known terrorist activity, consorting with known militants, armed men travelling in trucks in areas under the control of Al-Qaeda in the Arabian Peninsula, suspicious camps in AQ-controlled area); and (iii) signatures that can be either legally adequate or legally inadequate (groups of armed men travelling towards conflict, operating an AQ training camp, training to join $\mathrm{AQ}$, facilitators, rest areas). ${ }^{53}$

There are concerns in relation to some of the second and third categories, for example the abovementioned signature 'military-age male in area of known terrorist activity'. It has been reported that when us counts civilian casualties, it 'counts all military-age males in a strike zone as combatants, according to several administration officials, unless there is explicit intelligence posthumously proving them innocent. 54 This is arguably a flawed criteria for distinguishing between civilians and combatants, it also circumvents the precautions and presumptions to be applied in situations of doubt and, thereby, effectively removes all meaningful safeguards provided by humanitarian law against the infliction of excessive incidental harm on the civilian population. ${ }^{55}$

\section{$4 \quad$ Lethal Autonomous Robotics}

Robotic weapons can be divided into the following three categories, depending on the degree of direct control exercised by a human operator.

53 Ibid 94-103.

54 Jo Becker and Scott Shane, 'Secret "Kill List" Proves a Test of Obama's Principles and Will' The New York Times (New York, 29 May 2012): 'It is also because Mr Obama embraced a disputed method for counting civilian casualties that did little to box him in. It in effect counts all military-age males in a strike zone as combatants, according to several administration officials, unless there is explicit intelligence posthumously proving them innocent.'

55 Melzer (n 2) 25. Precaution must be taken before launching an attack and against the effects of attacks, see AP I arts 57 and 58 . 
(1) Human-controlled (human-in-the-loop) systems: Robotic weapons which are remotely controlled by a human operator. (2) Human-supervised (humanon-the-loop) systems: Robotic weapons which can carry out a targeting process independently from human command, but which remain under the real-time supervision of a human operator who can override any decision to attack. (3) Autonomous (human-out-of-the-loop) systems: Robotic weapons which can search, identify, select, and attack targets without the real-time control by a human operator. ${ }^{56}$

The use of LARs where targeting decisions could be taken by the robots themselves would be more than an upgrade of the kinds of weapons used, it would also entail but also a change in the identity of those who use them. Official statements from Governments with the ability to produce LARs indicate that their use during armed conflict or elsewhere is not currently envisioned. ${ }^{57}$ More specifically, the us Department of Defence has in its unmanned systems roadmap stated that 'For the foreseeable future, decisions over the use of force and the choice of which individual targets to engage with lethal force will be retained under human control in unmanned systems. ${ }^{58}$ The UK Ministry of Defence has made similar statements. ${ }^{59}$ However, Sparrow argues that it appears increasingly likely that robots will eventually be entrusted with decisions about target identification and destruction. ${ }^{60}$ Similarly, special rapporteur Heyns has expressed fear that initial intentions could in the future be cast aside. Under the currently envisaged scenario, humans will at least remain part of what may be called the 'wider loop': they will programme the ultimate goals into the robotic systems and decide to activate and, if necessary, deactivate them, while autonomous weapons will translate those goals into tasks and execute them without requiring further human intervention. ${ }^{61}$

The United States, Israel, United Kingdom and South Korea do operate defensive systems for manned ships and installations that have humansupervised automatic modes, some of these systems have been operating for decades. They have various degrees of autonomy and lethality. These include us Phalanx anti-air warfare systems against anti-ship missiles and aircraft; us

\footnotetext{
$56 \quad$ Melzer (n 2) 6.

57 HR Council Report 2013 (n 2) [28]-[29]. See also Robert Sparrow, 'Killer Robots' (2007) 24 Journal of Applied Philosophy 62, 68.

58 Us Department of Defense, 'Unmanned Systems Integrated Road Map FY 2011-2036' (2012) 50 .

59 U K Ministry of Defence, 'The uk Approach to Unmanned Aircraft Systems' (2011) 5-4.

6o $\quad$ Sparrow (n 57$) 64$.

61 HR Council Report 2013 (n 2) [29], [40]; Melzer (n 2) 9.
} 
C-RAM system against incoming artillery, rockets and mortar rounds; Israel's Harpy system designed to detect, attack and destroy radar emitters, UK Taranis combat drone prototype can autonomously search, identify and locate enemies but can only engage with a target when authorized by mission command. It can also defend itself against enemy aircraft; Samsung Techwin surveillance and security guard robots (SGR), deployed in the demilitarized zone between North and South Korea, detect targets through infrared sensors. They are currently operated by humans but have an 'automatic mode'. ${ }^{62}$ Most of these may be described as automatic systems and should be distinguished from autonomous systems, where the latter is capable of understanding higher level intent and direction. ${ }^{63}$

Potential reasons why LARs are developed is that such systems offer higher force projection (preserving the lives of one's own soldiers) and force multiplication (allowing fewer personnel to do more). Humans have in some respects become the weakest link in the military arsenal and are thus being taken out of the decision-making loop. The reaction time of autonomous systems far exceeds that of human beings. Special rapporteur Heyns lists some advantages with LARs from a humanitarian perspective. LARs will not be susceptible to some of the human shortcomings that may undermine the protection of life. Typically they would not act out of revenge, panic, anger, spite, prejudice or fear. Moreover, unless specifically programmed to do so, robots would not cause intentional suffering on civilian populations, for example through torture. Robots also do not rape. However robots lack qualities such as common sense, appreciation of the larger picture, understanding of the intentions behind people's actions, understanding of values, anticipation of the direction in which events are unfolding, compassion and intuition all relevant for armed conflicts. There are also built-in constraints that humans have against going to war or otherwise using force, including the aversion to getting killed, losing loved ones, or having to kill other people. ${ }^{64}$ The use of LARs might does decrease the threshold against using military force.

Does this mean that States should not attempt to develop any military technology that reduces the brutality of armed conflict or lowers overall deaths through greater accuracy? Special rapporteur Heyns argues that there is a

\footnotetext{
62 'Unmanned Systems Integrated Road Map' (n 58) 50; HR Council Report 2013 (n 2) [45]; Melzer (n 2) 12-13.

63 'The u k Approach to Unmanned Aircraft Systems' (n 59) 2-3.

64 Gary E Marchant and others, 'International Governance of Autonomous Military Robots' (2011) 12 Columbia Science and Technology Law Review 272, 275; HR Council Report 2013 (n 2) [51], [53]-[55], [57].
} 
difference between reducing the risk that armed conflict poses to those who participate in it, and the situation where one side is no longer a 'participant' in armed conflict inasmuch as its combatants are not exposed to any danger. ${ }^{65}$ The next question is whether LARs are capable of complying with the requirements of IHL.

There are several potential factors that may impede the ability of LARs to operate according to the rule of distinction, including the technological inadequacy of existing sensors, a robot's inability to understand context, and the difficulty of applying of IHL language in defining non-combatant status in practice, which must be translated into a computer programme. With the proliferation of asymmetric warfare and non-international armed conflicts, often in an urban environment, LARs will have difficulties to distinguish civilians from otherwise lawful targets. This is especially so where complicated assessments such as 'direct participation in hostilities' discussed in section 3.3 above. However, humans are not necessarily superior to LARs in their ability to distinguish. In some contexts technology can offer increased precision. ${ }^{66}$

Further, the open-endedness of the rule of proportionality combined with the complexity of circumstances may result in undesired and unexpected behaviour by LARs, with deadly consequences. Humans may be superior in the ability to 'frame' and contextualize the environment. ${ }^{67}$

The assumption is that robots have no moral agency and as a result cannot be held responsible in any recognizable way if they causing injuries or death in violation of IHL or IHRL. Who is to be held responsible? Candidates for legal responsibility include the software programmers, those who build or sell hardware, military commanders, subordinates who deploy these systems and political leaders. Traditional command responsibility may in certain cases be inapplicable because of the requirement that the commander have knowledge that a subordinate is or is about to commit a crime and the commander fails to act. ${ }^{68}$ Military commanders will not always be able to understand the programming of LARs in a sufficient manner. The use of autonomous weapons therefore involves a risk that military personnel will be held responsible for the actions of machines whose decisions they did not control. The more autonomous the systems are, the larger this risk looms. If the machines are really

\footnotetext{
65 HR Council Report 2013 (n 2) [6o].

66 Ibid [67]-[69].

67 Ibid [71].

68 Protocol Additional to the Geneva Conventions of 12 August 1949 and Relating to the Protection of Victims of International Armed Conflicts (Protocol I) (adopted 8 June 1977) 1125 United Nations Treaty Series 2 arts 86(2) and 87.
} 
choosing their own targets then we cannot hold the military commander responsible for the deaths that ensue. This fear is arguably unwarranted. Unless humanity has totally surrendered to the rule of robots, some person still has to take the decision to deploy the robot and that person could be held accountable. It will also be problematic to assign strict liability on the manufacturer or programmers because the manufacturing of a LAR will typically involve a vast number of people and companies, and no single person will be likely to understand the complex interactions between the constituent components of LARs. It will only be to assign responsibility for violations of IHL and IHRL in such cases if it was a result of negligence on the part of the design/programming team. A reasonable option is to assign responsibility in advance and/or share the responsibility. ${ }^{69}$ It is conceivable that the use of fully autonomous robots due to flaws in software may result in unintended violations of international law. Melzer argues that while it may not always be possible in such cases to assign individual criminal responsibility for the resulting damage, this observation is not robot-specific but applies to any other malfunctioning weapon or machine. In such cases, the lack of criminal culpability on the level of individual State agents has no bearing on the continued legal responsibility of States both for the use of these weapons and for any internationally wrongful damage they may cause. ${ }^{70}$ The present rules may be inadequate to address autonomous weapons systems. In cases of injuries or death caused by LARs, the first candidate for attribution of accountability is arguably the person who took the decision to deploy the robot.

\section{5}

\section{Conclusions and Recommendations}

The use of drones and other robotic weapons concerns IHL, IHRL and the law on the use of force. All three bodies of law may be applicable to a situation, each of them regulates different aspects of the use of force. In order to use drones or other robotic weapons on an extraterritorial basis, such use must be lawful both in relation to the territorial state and the killed/injured individuals. Unlawful violations of a foreign State's territory cannot be justified even if the targeted individual is a legitimate military target. Equally, the existence of a situation of self-defence or consent of the territorial state cannot justify direct attacks against individuals who do not constitute legitimate military targets

69 Sparrow (n 57) 67, 69-73; HR Council Report 2013 (n 2) [76]-[79], [81].

$70 \quad \operatorname{Melzer}(\mathrm{n} 2) 39$. 
under IHL, alternatively, who do represent an imminent threat justifying the use of lethal force under IHRL. ${ }^{71}$

Turning to autonomous weapons systems a reasonable conclusion is that the military commander deploying such systems have the ultimate responsibility. There are two reasonable options if a military commander knowingly deploys an autonomous weapons that by its nature, design is beyond the control of that commander and inherently indiscriminate. First, one could impose criminal responsibility on the commander for all violations of IHL and IHRL caused by the weapon. Second, the commander could also be subject to individual criminal responsibility merely be deploying such a weapon if it is prohibited in the same way as some other weapons. ${ }^{72}$

To summarize, it is arguably not necessary to adopt new, specific rules on drones. Missiles launched by a drone present the same legal issues as any other weapon system, the principles of necessity, distinction, proportionality and precaution still applies. To the extent drones at the present time are used in an illegitimate manner is rather a question of non-compliance with the existing law, less an absence of adequate rules. However, a different approach may be justified when it comes to autonomous weapons systems capable of taking targeting decisions. The present declared position by States that decisions over the use of force and the choice of which individual targets to engage with lethal force will be retained under human control may change. It is probably easier to adopt rules in this area before systems have been developed and deployed. Thus, this is the time to discuss whether there is a need for specific rules on autonomous weapons systems capable of taking targeting decisions.

\footnotetext{
71 Ibid 21-22.

72 cf Rome Statute of the International Criminal Court (adopted 17 July 1998) 2187 United Nations Treaty Series 90 art 8(2)(b)(xvii)-(xx) and (e)(xiii-xv).
} 